Performance indicators of broilers fed propolis and bee pollen additive

Proizvodni pokazatelji brojlera hranjenih dodatkom propolisa i pčelinjega peluda

Prakatur, I., Miškulin, I., Galović, D., Steiner, Z., Lachner, B., Domaćinović, $M$.

Poljoprivreda/Agriculture

ISSN: $1848-8080$ (Online)

ISSN: 1330-7142 (Print)

http://dx.doi.org/10.18047/poljo.25.1.10

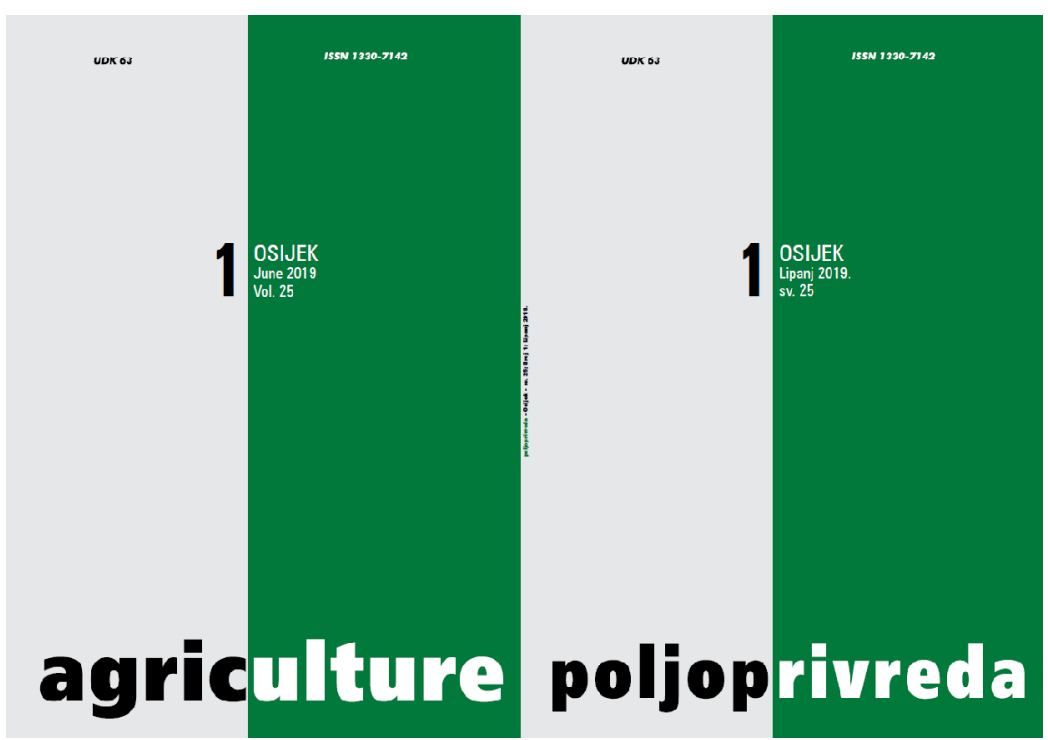

Fakultet agrobiotehničkih znanosti Osijek, Poljoprivredni institut Osijek

Faculty of Agrobiotechnical Sciences Osijek, Agricultural Institute Osijek 
ISSN $1330-7142$

$U D K=636.5: 636.084 .5$

DOI: $10.18047 /$ poljo.25.1.10

\title{
PERFORMANCE INDICATORS OF BROILERS FED PROPOLIS AND BEE POLLEN ADDITIVE
}

\author{
Prakatur, I. ${ }^{(1)}$, Miškulin, I.(2), Galović, D. ${ }^{(1)}$, Steiner, Z.(1), Lachner, B. ${ }^{(3)}$ Domaćinović, M. ${ }^{(1)}$
}

Original scientific paper

Izvorni znanstveni članak

\begin{abstract}
SUMMARY
The aim of this study was to determine the effect of diet supplementation with propolis and/or bee pollen on the performance indicators of broilers. This experimental study was conducted on 200 Ross 308 broilers equally distributed by sex and divided into five groups. Throughout the whole study the control group of chickens was fed feed mixture. Feed mixture fed to the experimental groups of chickens contained additives (propolis and/or bee pollen, each supplement separately or in combination in a certain proportion). The average values of broilers body weight were significantly higher on $7^{\text {th }}(p=0.001), 14^{\text {th }}, 21^{\text {st }}, 28^{\text {th }}, 35^{\text {th }}(p<0.001)$ and $42^{\text {nd }}$ $(p=0.002)$ day of feeding in the experimental groups of broilers compared to the control group. The average values of broilers weight gain were significantly higher on $1^{\text {st }}(p<0.001), 2^{\text {nd }}(p=0.002), 3^{\text {rd }}(p<0.001), 4^{\text {th }}(p=0.029)$ and $5^{\text {th }}(p=0.009)$ week of feeding in the experimental groups of broilers compared to the control group. This study has undoubtedly shown that propolis and bee pollen have significant positive effect on performance indicators of broilers.
\end{abstract}

Key words: bee pollen, body weight, broilers feeding, performance indicators, propolis, weight gain

\section{INTRODUCTION}

High growth rate and feed efficiency are the two main targets in poultry production (Sugiharto, 2016). The forbidden increase in investment costs, especially the cost of feed, is among the limitations in commercial broiler production. Achieving higher net yields and reducing high feed costs are the main challenges that many research strategies try to solve, notably by usage of feed supplements in the diets of broilers (OleforuhOkoleh et al., 2015). For several decades, antibiotics have been widely used in the chicken diet (Hascik et al., 2016). However, the use of antibiotics in broilers feeding has resulted in numerous problems such as the development of antibiotic-resistant bacteria and the appearance of drug residues in final products that can be harmful to consumer health. Therefore, the use of antibiotics as a growth promoter is no longer acceptable and is prohibited in the European Union countries (Goodarzi et al., 2014). As a consequence, natural substances such as propolis and bee pollen have received increased attention as possible antibiotic growth promoter substitutions in chicken diet due to their wide range of potential beneficial effects (Hascik et al., 2016).

Propolis and bee pollen belong to a group of natural substances of animal and vegetable origin with a particularly expressed antioxidant and antimicrobial properties (Krocko et al., 2012; Babaei et al., 2016). The bioactive components of propolis and bee pollen include flavonoids, phenolic acids and their derivatives which are also responsible for the bactericidal, antiviral, antifungal, analgesic, anti-inflammatory, antioxidant, immunostimulating and immunomodulating effects of these compounds in humans and animals (Talas and Gulhan, 2009; Babinska et al., 2012; Krocko et al., 2012; Babaei et al., 2016). The results of the research that has studied the effect of

(1) Assist. Prof. Ivana Prakatur, PhD., Assist. Prof. Dalida Galović, Ph.D., Prof. Zvonimir Steiner, Ph.D., Prof. Matija Domaćinović, Ph.D. - Josip Juraj Strossmayer University of Osijek, Faculty of Agrobiotechnical Sciences Osijek, Vladimira Preloga 1, Osijek, Croatia (2) Assist. Prof. Ivan Miškulin, Ph.D. (ivan.miskulin@mefos.hr) - Josip Juraj Strossmayer University of Osijek, Faculty of Medicine Osijek, Josipa Huttlera 4, Osijek, Croatia (3) Božica Lachner, DVM - Agricultural Food Company Valpovo Ltd., A. B. Šimića 27, Valpovo, Croatia 
propolis and bee pollen on broilers production indicators are not unambiguous and there are still no recommendations on the quantities of these substances that would result in the best production results (Omar et al., 2002; Khojasteh Shalmany and Shivazad, 2006; Seven et al., 2008; Angelovicova et al., 2010; Hascik et al., 2010, 2012, 2016; Tekeli et al., 2011; Attia et al., 2013, 2014; Mahmoud et al., 2013; Eyng et al., 2014; Kleczek et al., 2014; Hosseini et al., 2016; Zafarnejad et al., 2017). The aim of this study was to determine the effect of diet supplementation with propolis and/or bee pollen on the performance indicators of broilers.

\section{MATERIAL AND METHODS}

\section{Animals and diets}

The study included a total of 200 day-old chickens of the Ross 308 provenance. The fattening trial of the chickens was carried out on a family farm in Eastern Croatia under the supervision of the Division for Animal Production and Biotechnology, Faculty of Agrobiotechnical Sciences Osijek, Josip Juraj Strossmayer University of Osijek. The experimental protocol was approved by the Committee for Animal Welfare of the Faculty of Agrobiotechnical Sciences Osijek, Josip Juraj Strossmayer University of Osijek. Total of 200 chickens of the Ross 308 provenance, evenly distributed sexes, were randomly divided into 5 groups (40 chickens in each group), one of which was the control group $(\mathrm{K})$ and the other four experimental groups (P1, P2, P3, P4). For the purpose of more effective monitoring of all the investigated indicators, on the seventh day of the trial all the chickens were marked with a leg ring. During the study all the groups of chickens were fattened under the same conditions (Klaric et al., 2018a). Temperature, humidity and lighting in the facility were maintained within optimum limits according to the manufacturer's recommendations for Ross 308 hybrid (Aviagen, 2014). Fattening was conducted on the wooden sawdust, and lasted for 6 weeks (42 days). During the study, feed and water were given to chickens' ad libitum (Klaric et al., 2018a).

From days 1-21 of the study chickens were fed a mixture of starter, and from days 22-42 of the study they were fed a finisher mixture. The composition and calculated analyses of feed mixtures used in the broilers feeding are shown in Table 1. Throughout the study the control group $(\mathrm{K})$ of chickens was fed a standard feed mixture without additives, while the experimental groups of chickens (P1, P2, P3, P4) were fed feed mixtures containing additives - propolis and/or bee pollen as follows: P1 group: feed mixture $+0.25 \mathrm{~g}$ of propolis $/ \mathrm{kg}$ of feed mixture $+20 \mathrm{~g}$ of bee pollen/ $\mathrm{kg}$ of feed mixture; P2 group: feed mixture $+0.5 \mathrm{~g}$ of propolis $/ \mathrm{kg}$ of feed mixture; $\mathrm{P} 3$ group: feed mixture $+1.0 \mathrm{~g}$ of propolis $/ \mathrm{kg}$ of feed mixture; P4 group: feed mixture $+20 \mathrm{~g}$ of bee pollen $/ \mathrm{kg}$ of feed mixture. Blending of propolis and bee pollen into the feed mixture was done in a vertical mixer (Briketstroj Ltd., Valpovo, Croatia) (Klaric et al., 2018a).
Table 1. The composition and calculated analysis of feed mixtures used in the broilers feeding.

Tablica 1. Sastav i izračunata analiza krmnih smjesa korištenih u hranidbi brojlera.

\begin{tabular}{|c|c|c|}
\hline $\begin{array}{l}\text { Fodders, \% } \\
\text { Krmiva, \% }\end{array}$ & Starter & Finisher / Finišer \\
\hline & 1-21 day / 1-21 dan & 22-42 day /22-42 dana \\
\hline Corn grain & 45.00 & 46.10 \\
\hline Flour middling & 2.80 & 3.00 \\
\hline Dehydrated alfalfa & 2.80 & 4.00 \\
\hline Soybean meal & 20.20 & 10.00 \\
\hline Sunflower meal & 4.00 & 4.00 \\
\hline Yeast & 4.00 & 3.00 \\
\hline Full fat soybean & 12.40 & 20.00 \\
\hline Vegetable oil & 3.70 & 5.00 \\
\hline $\begin{array}{l}\text { Monocalcium } \\
\text { phosphate }\end{array}$ & 1.20 & 1.20 \\
\hline Limestone & 1.60 & 1.40 \\
\hline Salt & 0.30 & 0.30 \\
\hline Premix ${ }^{*}$ & 1.00 & 1.00 \\
\hline Pigozen 801 & 1.00 & 1.00 \\
\hline Total & 100.00 & 100.00 \\
\hline \multicolumn{3}{|c|}{ Calculated analysis / Izračunata analiza } \\
\hline Crude protein, $\%$ & 21.02 & 19.15 \\
\hline Crude fat, \% & 8.36 & 10.96 \\
\hline Crude fiber, $\%$ & 4.96 & 5.05 \\
\hline Lysine, \% & 1.11 & 0.96 \\
\hline Methionine, \% & 0.66 & 0.61 \\
\hline Tryptophan, \% & 0.26 & 0.23 \\
\hline Calcium, \% & 1.04 & 0.98 \\
\hline Phosphorous, \% & 0.70 & 0.67 \\
\hline $\mathrm{ME}, \mathrm{MJ} / \mathrm{kg}$ & 12.30 & 13.10 \\
\hline
\end{tabular}

*Each $1 \mathrm{~kg}$ of premix contained: Vitamin A 1200000 IU; Vitamin D3 200000 IU; Vitamin E 3000 mg; Vitamin K3 250 mg; Vitamin B1 150 mg; Vitamin B2 600 mg; Vitamin B6 200 mg; Vitamin B12 1 mg; Folic acid 50 mg; Niacin 4400 $\mathrm{mg}$; Ca Panthothenate $1500 \mathrm{mg}$; Biotin 10mg; Choline chloride $50000 \mathrm{mg}$; Iron 5000 mg; Copper 700 mg; Manganese 8000 mg; Zinc 5000 mg; lodine 75 mg; Cobalt 20 mg; Magnesium 750 mg; Selenium 15 mg; Antioxidant BHT 10000 mg; Methionine 100000 mg; Herbal carrier $1000 \mathrm{~g}$

Samples of raw propolis and bee pollen used in this study were obtained from apiaries located in naturally preserved areas of continental Croatia (around the city of Osijek, eastern Croatia). Propolis and bee pollen were crushed and, in powder form, were mixed with dry feed mixture by a vertical mixer. Bearing in mind that the biological activity of propolis and bee pollen depends on the components of polyphenolic fraction, mainly flavonoids, in propolis and bee pollen samples used in this study the amount of total flavonoids, expressed as equivalents of quercetin was determined by colorimetric method according to Chang et al. (2002). The analysis was performed at the Department of Health Ecology within the Croatian Institute of Public Health 
in Zagreb, Croatia accredited according to HRN EN ISO/IEC 17025:2000. The analysis had shown that the amount of total flavonoids in propolis used in this study was $248.24 \mathrm{mg} / \mathrm{g}$, while the amount of total flavonoids in bee pollen used in this study was $31.80 \mathrm{mg} / \mathrm{g}$, both expressed as equivalents of quercetin.

\section{Measurements and analysis}

Individual body weight (BW) of each broiler was measured on $1^{\text {st }}, 7^{\text {th }}, 14^{\text {th }}, 21^{\text {st }}, 28^{\text {th }}, 35^{\text {th }}$ and $42^{\text {nd }}$ day of the feeding trial using an electronic scale Avery Berkel FX 220. Based on the measured values the average value of body weight of broilers from all the groups has been calculated, while difference between body weights was used for the calculation of weight gains (WG). During the trial, feed consumption (FC) was recorded in weekly intervals for each group of broilers. Based on the total amount of consumed feed and overall weight gain, feed conversion ratio (FCR) was calculated for each week.

\section{Statistical analysis}

Descriptive statistics were used for data processing and analyzed using statistical package Statistica for Windows 2010 (version 10.0, Stat Soft Inc., Tulsa, OK). Normality of data distribution was tested by the Shapiro-
Wilkinson test. The numerical variables were described as mean and standard deviation. Kruskal-Wallis test was used for the comparison of numerical variables among the groups. Fisher's exact test was used for the comparison of categorical variables between the groups. On all statistical analyses, two-sided $p$-values of 0.05 and lesser ones were considered significant. Different lowercase letters at the level of statistical significance of $p<0.05$ assigned to the individual values in the tables indicate a statistically significant difference while the same lowercase letters assigned to the certain values in the tables indicate the absence or lack of statistically significant differences.

\section{RESULTS AND DISCUSSION}

The average values of the measured body weights of broilers from all the groups according to the feeding period are shown in Table 2. Statistical analysis has shown that there was a statistically significant difference in average body weight of broilers between the experimental groups and the control group on the $7^{\text {th }}(p=0.001), 14^{\text {th }}(p<0.001), 21^{\text {st }}(p<0.001), 28^{\text {th }}$ $(p<0.001), 35^{\text {th }}(p<0.001)$ and $42^{\text {nd }}(p=0.002)$ day of the feeding trial.

Table 2. Body weights of broilers by the feeding period (g) (Klaric et al. (2018b).

Tablica 2. Tjelesne mase brojlera prema razdobljima tova (g) (Klaric $i$ sur. (2018b).

\begin{tabular}{|c|c|c|c|c|c|c|}
\hline \multirow{2}{*}{$\begin{array}{l}\text { Days } \\
\text { Dani }\end{array}$} & \multicolumn{5}{|c|}{$\begin{array}{c}\text { Groups of broilers / Skupine brojlera } \\
\pm \mathrm{s}\end{array}$} & \multirow{2}{*}{${ }^{*} p$} \\
\hline & K & P1 & $\mathrm{P} 2$ & P3 & P4 & \\
\hline $1^{\text {st }}$ & $41.23 \pm 1.40$ & $41.25 \pm 1.63$ & $41.30 \pm 1.65$ & $41.25 \pm 1.66$ & $41.23 \pm 1.51$ & $>0.999$ \\
\hline $7^{\text {th }}$ & $125.95^{\mathrm{a}} \pm 18.39$ & $129.79^{\mathrm{ab}} \pm 17.05$ & $131.95^{\mathrm{ab}} \pm 14.61$ & $135.59^{b} \pm 15.17$ & $141.85^{c} \pm 17.43$ & 0.001 \\
\hline $14^{\text {th }}$ & $303.89^{\mathrm{ac}} \pm 62.97$ & $307.13^{\mathrm{a}} \pm 43.84$ & $324.50^{\text {cd }} \pm 47.09$ & $341.23^{\mathrm{bd}} \pm 39.74$ & $352.36^{b} \pm 40.36$ & $<0.001$ \\
\hline $21^{\text {st }}$ & $607.67^{a} \pm 112.42$ & $655.51^{b} \pm 93.47$ & $670.33^{b} \pm 95.86$ & $719.90^{c} \pm 84.90$ & $743.46^{c} \pm 82.16$ & $<0.001$ \\
\hline $28^{\text {th }}$ & $1018.03^{a} \pm 173.25$ & $077.10^{\mathrm{ad}} \pm 138.90$ & $1106.30^{\mathrm{bd}} \pm 154.14$ & $1140.51^{b} \pm 103.76$ & $1187.13^{c} \pm 120.58$ & $<0.001$ \\
\hline $35^{\text {th }}$ & $1526.03^{a} \pm 250.78$ & $1581.15^{\mathrm{ab}} \pm 191.95$ & $1599.95^{\mathrm{ab}} \pm 251.52$ & $1665.33^{b} \pm 152.78$ & $1753.21^{c} \pm 192.93$ & $<0.001$ \\
\hline $42^{\text {nd }}$ & $1961.67^{\mathrm{a}} \pm 289.95$ & $1985.97^{\mathrm{a}} \pm 214.49$ & $1999.65^{\mathrm{ac}} \pm 291.48$ & $2083.59^{b c} \pm 185.28$ & $2146.31^{b} \pm 229.17$ & 0.002 \\
\hline
\end{tabular}

*Kruskal-Wallis test; =mean; $s=$ standard deviation; means within rows without common superscripts differ significantly ${ }^{a, b, c} p<0.05$

The present study showed that average values of body weight of broilers were significantly higher on $7^{\text {th }}$, $14^{\text {th }}, 21^{\text {st }}, 28^{\text {th }}, 35^{\text {th }}$ and $42^{\text {nd }}$ day of feeding trial in the experimental groups of broilers compared to the control group, pointing to the fact that propolis and bee pollen have positive effect on body weight of broilers. These results are consistent with the results of other authors (Omar et al., 2002; Khojasteh Shalmany and Shivazad, 2006; Seven et al., 2008; Angelovicova et al., 2010; Hascik et al., 2010, 2012; Attia et al., 2013, 2014; Hosseini et al., 2016; Zafarnejad et al., 2017) who have all determined positive effect of propolis and bee pollen on body weight of broilers. However, these results are opposite to the results of Hascik et al. (2016) and Kleczek et al. (2014) who did not establish statistically significant differences in body weights between the control and experimental groups of broilers. The results of this study are also opposite to the results of the study by Mahmoud et al. (2013) who found out that the addition of propolis had negative effect on body weight of broilers. This study showed that average body weight increase of broilers from a particular group is consistent with the increase in the quantity of added propolis. Furthermore, the study revealed that propolis and bee pollen do not have a synergistic effect in terms of increasing body weights of broilers because broilers from $\mathrm{P} 1$ group (which received a combination of propolis and bee pollen) did not have a greater body weight in relation to broilers from P4 group that received only bee pollen. These results are consistent with the results of other similar studies (Attia et al., 2013, 2014). Finally, this study showed that bee pollen is more effective in increasing body weight of broilers compared 
to propolis because during all 6 weeks of the feeding trial the broilers from P4 group (which were supplemented with bee pollen alone) had the highest body weights compared to the broilers from the other experimental groups and broilers from the control group. The latter is opposite to the results of aforementioned similar studies (Attia et al., 2013, 2014) which determined that bee pollen and propolis are equally effective in enhancing growth performance of broilers.
The average values of the calculated weight gains of broilers from all the groups by the feeding period are shown in Table 3. Statistical analysis has shown that there was a statistically significant difference in average weight gain of broilers between the experimental groups and the control group on the $1^{\text {st }}(p<0.001)$, $2^{\text {nd }}(p=0.002), 3^{\text {rd }}(p<0.001), 4^{\text {th }}(p=0.029)$ and $5^{\text {th }}$ $(p=0.009)$, week of the feeding trial.

Table 3. Weekly weight gains of broilers (g).

Tablica 3. Skupine brojlera prema tjednima tova (g).

\begin{tabular}{|c|c|c|c|c|c|c|}
\hline \multirow[t]{2}{*}{$\begin{array}{l}\text { Weeks } \\
\text { Tjedni }\end{array}$} & \multicolumn{5}{|c|}{$\begin{array}{c}\text { Groups of broilers / Skupine brojlera } \\
\pm \mathrm{s}\end{array}$} & \multirow{2}{*}{${ }^{*} p$} \\
\hline & K & P1 & P2 & P3 & P4 & \\
\hline $1^{\text {st }}$ & $84.74^{a} \pm 17.20$ & $88.54^{\mathrm{ab}} \pm 16.01$ & $90.65^{\mathrm{ab}} \pm 13.26$ & $94.26^{b} \pm 13.66$ & $100.63^{c} \pm 17.55$ & $<0.001$ \\
\hline $2^{\text {nd }}$ & $177.19^{a} \pm 55.68$ & $177.33^{\mathrm{a}} \pm 45.83$ & $192.55^{\mathrm{ab}} \pm 50.26$ & $205.64^{b} \pm 40.55$ & $210.41^{b} \pm 38.77$ & 0.002 \\
\hline $3^{\text {rd }}$ & $304.53^{a} \pm 106.41$ & $348.38^{b} \pm 97.72$ & $345.83^{b} \pm 93.27$ & $378.67^{b c} \pm 88.04$ & $391.10^{c} \pm 82.74$ & $<0.001$ \\
\hline $4^{\text {th }}$ & $410.36^{\mathrm{a}} \pm 66.18$ & $421.59^{\mathrm{ab}} \pm 57.09$ & $435.98^{\mathrm{b}} \pm 75.02$ & $420.62^{\mathrm{a}} \pm 36.25$ & $443.67^{b} \pm 52.10$ & 0.029 \\
\hline $5^{\text {th }}$ & $508.00^{\mathrm{a}} \pm 87.17$ & $504.05^{a} \pm 83.40$ & $493.65^{a} \pm 117.53$ & $524.82^{\mathrm{a}} \pm 68.36$ & $566.08^{b} \pm 94.89$ & 0.009 \\
\hline $6^{\text {th }}$ & $435.64 \pm 64.88$ & $404.82 \pm 75.78$ & $399.70 \pm 74.85$ & $418.26 \pm 68.27$ & $393.10 \pm 84.59$ & 0.123 \\
\hline
\end{tabular}

${ }^{*}$ Kruskal-Wallis test; =mean; $s=$ standard deviation; means within rows without common superscripts differ significantly ${ }^{a, b, c} p<0.05$

The average values of weight gain of broilers were significantly higher on $1^{\text {st }}, 2^{\text {nd }}, 3^{\text {rd }}, 4^{\text {th }}$ and $5^{\text {th }}$ week of the feeding trial in the experimental groups of broilers compared to the control group pointing to the fact that propolis and bee pollen have positive effect on weight gain of broilers. These results are consistent with the results of other authors (Omar et al., 2002; Khojasteh Shalmany and Shivazad, 2006; Seven et al., 2008; Tekeli et al., 2011; Attia et al., 2013, 2014; Hascik et al., 2015; Hosseini et al., 2016; Zafarnejad et al., 2017) who have all determined positive effect of propolis and bee pollen on weight gain of broilers. However, the results of this study are opposite to the results of the study by Mahmoud et al. (2013) and Eyng et al. (2014) who found out that the addition of propolis had negative effect on weight gain of broilers during the whole feeding period or during the first week of feeding.

The values of weekly feed consumption for all broiler groups are shown in Figure 1. Statistical analysis has shown that there was no statistically significant difference in average values of weekly feed consumption of broilers between the experimental groups and the control group on any week of the feeding trial $(p>0.999)$.

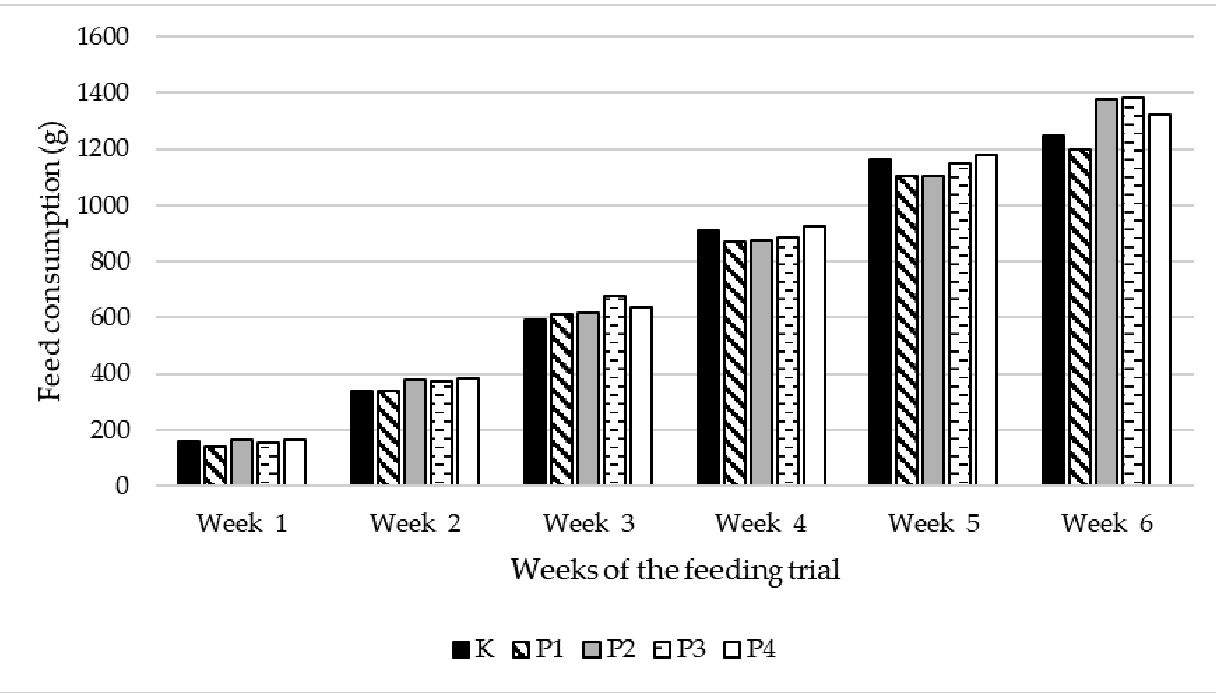

Figure 1. Feed consumption for all broiler groups according to the week of the feeding trial (Kruskal-Wallis test; $\boldsymbol{p}>\mathbf{0 . 9 9 9 )}$.

Slika 1. Konzumacija hrane u svim skupinama pilića prema tjednu tova (Kruskal-Wallis test; $p>0,999$ ). 
Regarding weekly feed consumption results of this study are only partially consistent with the results of some similar studies (Omar et al., 2002; Khojasteh Shalmany and Shivazad, 2006; Tekeli et al., 2011; Eyng et al., 2014) but are however, opposite to the results of the study by Mahmoud et al. (2013) and Attia et al. (2014).
The values of weekly feed conversion for all broiler groups are shown in Figure 2. Statistical analysis has shown that there was no statistically significant difference in values of weekly feed conversion between the experimental groups and the control group on any week of the feeding trial $(p>0.999)$.

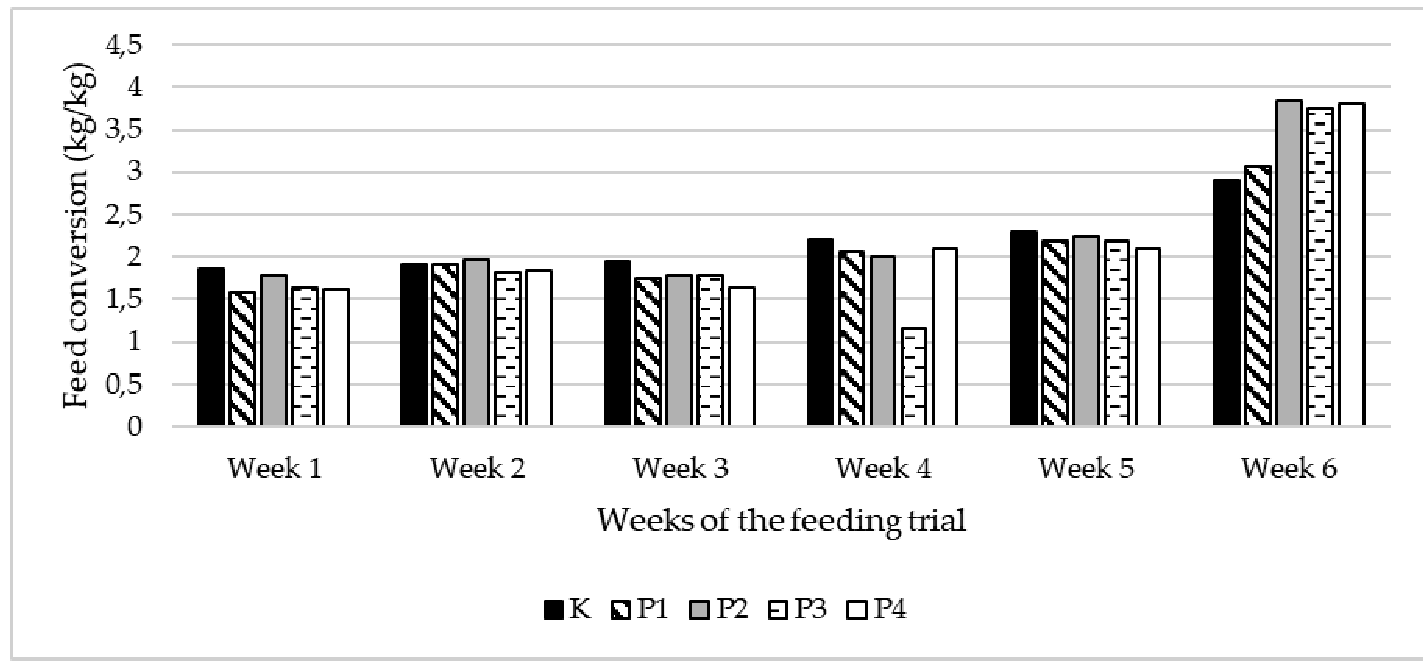

Figure 2. Feed conversion for all broiler groups according to the week of the feeding trial (Kruskal-Wallis test; p >0.999)

Slika 2. Konverzija hrane u svim skupinama pilića prema tjednu tova (Kruskal-Wallis test; $p>0,999$ ).

When analyzing feed conversion ratio by the group of broilers this study showed quite mixed results being consistent with the results of the study by Angelovicova et al. (2010) and only partially consistent with other similar studies (Omar et al., 2002; Khojasteh Shalmany and Shivazad, 2006; Attia et al., 2014; Eyng et al., 2014). Finally, the results of this study considering feed conversion ratio are opposite to the results of the study by Seven et al. (2008), Tekeli et al. (2011) and Mahmoud et al. (2013).

Considering positive effect of propolis and bee pollen on growth performance of broilers, determined in this study, it is important to point out that different authors interpret this positive effect in different ways. For example, Omar et al. (2002) point out that any substance having antimicrobial properties, such as propolis also has a considerable capacity to promote growth because it prevents the development of different sub-clinical infections which compromise the growth of chickens. Khojasteh Shalmany and Shivazad (2006) emphasized that higher consumption of feed, in chickens fed with the addition of propolis, is most likely the result of its positive effect on general health status of chickens. The same authors also believe that the feed with the addition of propolis is tastier for animals due to a mixture of resin, wax, honey and vanilla content and therefore animals prefer to consume it in larger quantity. In addition, the same authors speculate that the higher weight gain in animals fed the addition of propolis is probably caused by the high content of flavonoids in propolis which stimulate the appetite of animals and encourage them to greater feed consumption. According to these authors, better feed conversion ratio in animals fed with the addition of propolis can be explained with the high content of flavonoids which stimulate the appetite of animals, and better general health status of animals fed the addition of propolis compared to animals in the control group (Khojasteh Shalmany and Shivazad, 2006). In their explanation of the positive effect of propolis on the growth performance in chickens Seven et al. (2008) and Tekeli et al. (2011) emphasize several crucial facts as follows. The feed with the addition of propolis is tastier for animals. Due to the high content of flavonoids in propolis the feed with the addition of propolis improves general health of the animals. Due to the digestive effects of propolis the feed with the addition of propolis enables faster degradation of feed and its faster passage through the digestive tract of chickens which further triggers higher feed consumption in animals that has a positive effect on the intensity of weight gain (Seven et al., 2008; Tekeli et al., 2011). Angelovicova et al. (2010) attribute the positive effect of bee pollen on the body weight to the antioxidant properties of bee pollen related to the content of flavonoids in pollen. Eyng et al. (2014) think that the beneficial effects of the feed with the addition of propolis are attributed to the influence of propolis on chicken gut health. Namely, it has been proven that propolis limits the growth of pathogenic microorganisms in the chickens' intestines and moreover promotes the growth of beneficial bacteria such as lactobacilli and bifidobacteria resulting in the improvement of digestion and absorption in the intestine (Eyng et al., 2014). Attia 
et al. (2014), however, consider that the identified positive effects of propolis and/or bee pollen on the growth performance in broilers can predominantly be attributed to a variety of micronutrients present in propolis, or bee pollen, such as flavonoids, various vitamins and minerals, that all have positive effects on the health and metabolism of broilers. Furthermore, the authors point out how bee pollen has a useful role in protecting the health of the intestine and strengthens the immunity of chickens, thus, contributes to the positive effects of bee pollen on performance parameters in chickens (Attia et al., 2014). Finally, Zafarnejad et al. (2017) have concluded that the mode of action of propolis is not only due to its strong antibacterial properties but is probably also related to the presence of micronutrients with positive effects on chickens' health and metabolism which eventually results in improvement in broiler performance.

\section{CONCLUSION}

In conclusion, the present study undoubtedly determined that addition of propolis and/or bee pollen to feed mixtures has significant positive effects on performance indicators of broilers. Following the obtained results, it can further be concluded that the application of propolis and bee pollen as natural additives in broiler feeding significantly improves the broiler production. The promising and encouraging results of this study emphasize the importance of evaluating the administration level of the investigated supplements in order to maximize their efficacy in commercial broiler production.

\section{REFERENCES}

1. Angelovicova, M., Stofan, D., Mocar, K., \& Liptaiova, D. (2010). Biological effects of oilseed rape bee pollen and broiler's chickens performance. In Proceedings of the International Conference on Food Innovation, Foodlnnova (pp. 246-247). Valencia, Spain: Universidad politechnica de Valencia.

2. Attia, Y. A., Abd Al-Hamid, A. E., Ibrahim, M. S., Al-Harthi, M. A., Bovera, F., \& El-Naggar, A. Sh. (2014). Productive performance, biochemical and hematological traits of broiler chickens supplemented with propolis, bee pollen, and mannan oligosaccharides continuously or intermittently. Livestock Science, 164, 87-95. https://doi.org/10.1016/j.livsci.2014.03.005

3. Attia, A., Abd Al-Hamid, A. E., Ibrahim, M. S., Al-Harthi, M. A., \& El-Naggar, A. Sh. (2013). Effects of propolis and/ or bee pollen as alternatives to mannan oligosaccharides when given continuously or intermittently on production, and physiological performance of broilers. In Poultry Science Association 102nd Annual Meeting Abstracts, Poultry Science, 92(E-Suppl.1) (pp. 61-62). San Diego, California, USA: Poultry Science Association Inc.. https://www.poultryscience.org/psa13/abstracts/59.pdf

4. Aviagen (2014). Ross 308 Broiler: Performance Objectives. Aviagen Group, Huntsville, USA. http:// en.aviagen.com/assets/Tech_Center/Ross_Broiler/Ross308-Broiler-PO-2014-EN.pdf
5. Babaei, S., Rahimi, S., Torshizi, M. A. K., Tahmasebi, G., \& Miran, S. N. K. (2016). Effects of propolis, royal jelly, honey and bee pollen on growth performance and immune system of Japanese quails. Veterinary Research Forum, 7(1), 13-20.

6. Babinska, I., Kleczek, K., Szarek, J., \& Makowski, W. (2012). Modulating effect of propolis and bee pollen on chicken breeding parameters and pathomorphology of liver and kidneys in the course of natural infection with Salmonella enteritidis. Bulletin of the Veterinary Institute in Pulawy, 56(1), 3-8. https://doi.org/10.2478/v10213-012-0001-9

7. Eyng, C., Murakami, A. E., Duarte, C. R. A., \& Santos, T. C. (2014). Effect of dietary supplementation with an ethanolic extract of propolis on broiler intestinal morphology and digestive enzyme activity. Journal of Animal Physiology and Animal Nutrition, 98(2), 393-401. https://doi.org/10.1111/jpn.12116

8. Goodarzi, M., Nanekarani, S., \& Landy, N. (2014). Effect of dietary supplementation with onion (Allium cepa L.) on performance, carcass traits and intestinal microflora composition in broiler chickens. Asian Pacific Journal of Tropical Disease, 4(Suppl 1), S297-S301.

https://doi.org/10.1016/S2222-1808(14)60459-X

9. Hascik, P., Elimam, I., Garlik, J., Kacaniova, M., Cubon, J., Bobko, M., \& Abdulla, H. (2012). Impact of bee pollen as feed supplements on the body weight of broiler Ross 308. African Journal of Biotechnology, 11(89), 1559615599. https://doi.org/10.5897/AJB12.2239

10. Hascik, P., Elimam, I. 0., Krocko, M., Bobko, M., Kacaniova, M., Garlik, J., Simko, M., \& Saleh, A. A. (2015). The influence of propolis as supplement diet on broiler meat growth performance, carcass body weight, chemical composition and lipid oxidation stability. Acta Universitatis Agriculturae et Silviculturae Mendelianae Brunensis, 63(2), 411-418. http://doi.org/10.11118/actaun201563020411

11. Hascik, P., Melich, M., Kacaniova, M., Pal, G., Mihok, M., Cubon, J., Mellen, M., \& Vavrisinova, K. (2010). The influence of propolis application to meat utility on Ross 308 broiler chickens. Potravinarstvo, 4(2), 29-34.

12. Hascik, P., Trembecka, L., Bobko, M., Kacaniova, M., Cubon, J., Kunova, S., \& Bucko, 0. (2016). Effect of diet supplemented with propolis extract and probiotic additives on performance, carcass characteristics and meat composition of broiler chickens. Potravinarstvo, 10(1), 223-231.

13. Khojasteh Shalmany, S., \& Shivazad, M. (2006). The effect of diet propolis supplementation on Ross broiler chicks performance. International Journal of Poultry Science, 5(1), 84-88. https://doi.org/10.3923/ijps.2006.84.88

14. Klaric, I., Miskulin, I., Seric, V., Dumic, A., Jonjic, J., \& Miskulin, M. (2018a). The effects of propolis and bee pollen supplementation on biochemical blood parameters of broilers. Acta Veterinaria-Beograd, 68(2), 190 200. https://doi.org/10.2478/acve-2018-0017

15. Klaric, I., Domaćinović, M., Šerić, V., Miškulin, I., Pavić, M., \& Paradinović, K. (2018b). Effects of bee pollen and propolis on performance, mortality, and some haemato- 
logical blood parameters in broiler chickens. Slovenian Veterinary Research, 55(1), 23-34. https://doi.org/10.26873/SVR-385-2018

16. Kleczek, K., Wilkiewicz-Wawro, E., Wawro, K., Makowski, W., Murawska, D., \& Wawro, M. (2014). The effect of dietary propolis supplementation on the growth performance of broiler chickens. Polish Journal of Natural Sciences, 29(2), 105-117.

17. Krocko, M., Canigova, M., Bezekova, J., Lavova, M., Hascik, P., \& Duckova, V. (2012). Effect of nutrition with propolis and bee pollen supplements on bacteria colonization pattern in gastrointestinal tract of broiler chickens. Scientific Papers: Animal Science and Biotechnologies, 45(1), 63-67.

18. Mahmoud, U. T., Abdel-Rahman, M. A., \& Darwish, M. H. A. (2013). The effect of Chinese propolis supplementation on Ross broiler performance and carcass characteristics. Journal of Advanced Veterinary Research, 3(4), 154-160.

19. Oleforuh-Okoleh, V. U., Ndofor-Foleng, H. M., Olorunlekel, S.0., \& Uguru, J. 0. (2015). Evaluation of Growth Performance, Haematological and Serum Biochemical Response of Broiler Chickens to Aqueous Extract of Ginger and Garlic. Journal of Agricultural Science, 7(4), 167-173. https://doi.org/10.5539/jas.v7n4p167

20. Omar, R. E. M., Mahmoud, E. A., Karousa, M. M., \& Randa, S. A. (2002). Effects of additives propolis and nigella sativa seed oil on some behavioural patterns, performance products and blood parameters in Sasso chickens. Egyptian Poultry Science Journal, 21, 140-151.

21. Seven, T. P., Seven, I., Yilmaz, M., \& Simsek, U. G. (2008). The effects of Turkish propolis on growth and carcass characteristics in broilers under heat stress. Animal Feed Science and Technology, 146(1-2), 137148. https://doi.org/10.1016/j.anifeedsci.2007.11.003

22. Sugiharto, S. (2016). Role of nutraceuticals in gut health and growth performance of poultry. Journal of the Saudi Society of Agricultural Sciences, 15(2), 99-111. https://doi.org/10.1016/j.jssas.2014.06.001

23. Talas, Z. S., \& Gulhan, M. F. (2009). Effects of various propolis concentrations on biochemical and hematological parameters of rainbow trout (Oncorhynchus mykiss). Ecotoxicology and Environmental Safety, 72(7), 19941998. https://doi.org/10.1016/j.ecoenv.2009.04.011

24. Tekeli, A., Kutlu, H. R., \& Celik, L. (2011). Effects of $Z$. officinale and propolis extracts on the performance, carcass and some blood parameters of broiler chicks. Current Research in Poultry Science, 1(1), 12-23. https://doi.org/10.3923/crpsaj.2011.12.23

25. Zafarnejad, K., Afzali, N., \& Rajabzadeh, M. (2017). Effect of bee glue on growth performance and immune response of broiler chickens. Journal of Applied Animal Research, 45(1), 280-284. https://doi.org/10.1080/09712119.2016.1174130

\section{PROIZVODNI POKAZATELJI BROJLERA HRANJENIH DODATKOM PROPOLISA I PČELINJEGA PELUDA}

\section{SAŽETAK}

Cilj ovoga istraživanja bio je ispitati učinak hranidbe uz dodatak propolisa i/ili pčelinjega peluda na proizvodne pokazatelje brojlera. Ovaj pokus proveden je na 200 brojlera provenijencije Ross 308 ravnomjerno raspoređenih po spolu, koji su bili podijeljeni u pet skupina. Tijekom cijeloga pokusa kontrolna je skupina brojlera bila hranjena krmnom smjesom, dok su pokusne skupine brojlera hranjene istom krmnom smjesom uz dodatak propolisa i pčelinjeg peluda, svakim dodatkom zasebno ili u kombinaciji u određenome omjeru. Prosječne vrijednosti tjelesne mase brojlera bile su znatno više $7 .(p=0,001), 14 ., 21 ., 28 ., 35 .(p<0,001)$ $i$ 42. $(p=0,002)$ dana tova u pokusnim skupinama brojlera u usporedbi s kontrolnom skupinom. Prosječne vrijednosti prirasta bile su znatno više 1. $(p<0,001)$, 2. $(p=0,002), 3 .(p<0,001), 4 .(p=0,029)$ i $5 .(p=0,009)$ tjedna tova u pokusnim skupinama brojlera u usporedbi s kontrolnom skupinom. Ovo istraživanje je nedvojbeno pokazalo kako propolis i pčelinji pelud imaju značajan pozitivan učinak na proizvodne pokazatelje brojlera.

Ključne riječi: hranidba brojlera, pčelinji pelud, prirast tjelesne mase, proizvodni pokazatelji, propolis, tjelesna masa

(Received on November 15, 2018; accepted on May 10, 2019 - Primljeno 15. studenoga 2018.; prihvaćeno 10. svibnja 2019.) 